\title{
ESTUDIO NECROLÓGICO: SERGIO POLITOFF LIFSCHITZ O LA PERSEVERANCIA CREADORA DE UNA VIDA EMIGRANTE
}

Dr. Dr. h.c. José Luis Gużmán Dalbora*

1. El fin de una generación de penalistas chilenos; 2. Familia y años de formación; 3. Ciencia y abogacía hasta 1973; 4. El exilio; 5. Reencuentro con el tiempo perdido; 6. De vuelta en Europa; 7. El legado.

\section{El fin de una generación de penalistas chilenos.}

Los últimos cinco años, que son también los primeros del incierto siglo veintiuno, han resultado fatales para la ciencia penal chilena. Y por el renombre internacional de las personalidades que acaba de perder, puede afirmarse que el luto abruma a toda la Dogmática punitiva de nuestro tiempo.

Registremos las fechas que entran en consideración, según la secuencia de los decesos. Nos han dejado Álvaro Búnster Briceño (1920-2004), Francisco Grisolía Corbatón (1928-2005), Eduardo Novoa Monreal (1916-2006), Sergio Yáñez Pérez (1925-2006) y Juan Bustos Ramírez (1935-2008). Amén de la común vocación científica, son hombres a los que circunstancias de la vida, relaciones personales e idiosincrasia de su pueblo hicieron coincidir en varios aspectos. Nacen en fechas relativamente próximas, reciben influjos culturales semejantes, se comportaron de manera análoga en condiciones afines, por lo cual cabe considerarlos como miembros de una misma generación. Es aquella que fermentó en los años sesenta de la pasada centuria al abrigo del Seminario de Derecho penal y Medicina legal en la Facultad jurídica de la Universidad de Chile, catapultando interna y exteriormente el cultivo nacional de la disciplina, y a la que hoy la zarpa de la muerte deja desarbolada y en trance de completa consunción. Además, tres de ellos sufrieron un prolongado exilio, a raíz de sus convicciones y actividad políticas, durante la negra página clavada en la historia del país por la dictadura militar y satrapía civil que encabezó Augusto Pinochet Ugarte (1973-1990), ostracismo que, en otro caso —el de Grisolía, natural de Barcelona-, hubieron de arrostrar los padres al huir de las huestes franquistas y, para los que quedaron, como Yáñez y el propio Grisolía, se presentó en la forma de perder los inapreciables interlocutores de antaño y asistir al decaimiento intelectual resultante, espoleado por la intervención castrense de las Universidades y el provocado marasmo de los institutos científicos, como una suerte de exilio interno.

Pero hay más. Salvo Juan Bustos, quien fina en el ejercicio de la Presidencia de la Cámara de Diputados, motivo por el cual las exequias adoptaron

\footnotetext{
* Catedrático de Derecho penal y de Introducción a la Filosofía jurídica y moral en la Universidad de Valparaíso (Chile).
} 
Guzmán - Estudio Necrológico: Sergio Politoff Lifschitz...

la solemnidad oficial de los funerales de una autoridad del Estado, sus compañeros de generación mueren en un ambiente de silencio, poco celebrados por los coterráneos, en ratificación de ese lamentable rasgo de la comunidad chilena —una faceta característica de pueblos jóvenes, otrora uncidos al yugo colonial, que miran al porvenir sin conciencia de su identidad histórica - consistente en la tardanza en reconocer a sus hijos ilustres y la mezquindad de un rápido olvido. La potencia expresiva de dicho fenómeno es independiente del aporte cultural de la figura de que se trate y, por cierto, convoca en primerísimo lugar a los camaradas de labor científica, filosófica, artística, literaria o poética. Eduardo Novoa fallece en Santiago tras permanecer recluido en su casa con la fundada impresión de estar proscrito por la universidad y el medio especializado. El deceso de Álvaro Búnster sobreviene en la patria adoptiva, ese auténtico asilo contra la opresión que es México, donde se le lloró con lágrimas que la sequedad ocular del solar natal vierte con cuentagotas. El tránsito de Francisco Grisolía y Sergio Yáñez solicitó escuetas necrologías de periódico y algún acto institucional, obra más bien de amigos y estrechos colaboradores de los profesores fallecidos, que del plexo del entorno científico. A diferencia de lo que ocurre en otros contextos del orbe ante sucesos de tal significación, no proliferaron aquí seminarios, coloquios o congresos cuya convocatoria llevase nombres que enorgullecen a la Universidad chilena ${ }^{1}$; tampoco se ha publicado libros para recordar como es debido la trayectoria de todos ellos ${ }^{2}$, el número especial de alguna revista que conmemore el legado jurídico ${ }^{3}$, estudios necrológicos, en fin, nada que evoque y preserve de la usura del tiempo la contribución a la materia criminalista, amén de la estampa humana que generó el aporte. ¡Pero si pocos colegas del oficio acompañaron el cortejo fúnebre de algunos de estos estudiosos, según me comentó privadamente, con desencanto, un profesor del ramo!

Naturalmente, superiores impedimentos geográficos nos impidieron acudir al sepelio de uno de los integrantes postremos de la pléyade, don Sergio Politoff Lifschitz, cuya vida paralizó inopinada y devoradora enfermedad el día 26 de diciembre de 2009, en Rótterdam. Cuando la noticia llegó de los Países Bajos a

\footnotetext{
${ }^{1}$ Reserva hecha de iniciativas estudiantiles, como el Seminario de Actualidad Jurídica que vienen organizando anualmente, hace algo más de diez años, los jóvenes de la Facultad de Derecho de la Universidad de Valparaíso. Consignemos también que en las IV Jornadas Chilenas de Derecho Penal y Ciencias Penales, celebradas en la Universidad Austral de Chile durante noviembre de 2007, se leyó sendos homenajes a los profesores Búnster y Novoa.

${ }^{2}$ La excepción no provino de una universidad pública, sino de la iniciativa particular. Se trata del volumen Contribuciones criticas al sistema penal de la post modernidad, coordinado por Myrrna Villegas Díaz y publicado por la Universidad Central en memoria de Eduardo Novoa Monreal, Santiago de Chile, 2008. Véase, además, Novoa Monreal, Nacionalización, Derecho y propiedad. (Textos escogidos). Selección y Prólogo de Carlos Margotta. Editorial Arcis, Santiago de Chile, 2006. En lo que respecta a Bustos, el volumen de homenaje apareció en vida del agraciado y, por cierto, no en Chile, sino el Perú, con el título Modernas tendencias de Dogmática penal y Política criminal, bajo la dirección de José Urquizo Olaechea, Idemsa, Lima, 2007.

3 Sólo hace muy poco la Revista de Estudios de la Justicia, de la Facultad de Derecho de la Universidad de Chile, ha dedicado uno de sus números, el 11, de 2009, a la memoria de Juan Bustos.
} 
Chile, amigos y discípulos dedicaron a la memoria del hombre y el autor unas líneas cuya brevedad, determinada por las exigencias de los periódicos, no resta un ápice al sentimiento de admiración, respeto y gratitud que recogió siempre el penalista santiaguino entre sus colegas, alumnos y lectores en general. Las comunicaciones pusieron de relieve, además, el afecto a que se hizo acreedor por su amable, bondadosa humanidad, que él prodigó así a los íntimos como a quien deseaba acercarse a su lado para entablar una conversación cualquiera, de la cual el circunstante inexorablemente salía aprendiendo lecciones de ciencia y de vida, como si hubiese leído en la persona del interlocutor un Bildungsroman del siglo $\mathrm{XX}^{4}$.

Sólo el futuro decidirá cómo y cuánto será recordado este jurisconsulto. Nuestra necrología, que ha de plegarse al poder de configuración de la posteridad, sólo querría conjurar una pareja de riesgos. Apremiados por las tareas de la hora, bien posible parece que antiguos y nóveles compañeros universitarios se abstengan de trazar una imagen más acabada de Sergio Politoff. La plausibilidad de la previsión se acentúa respecto de los jóvenes, inmersos como están en una época que estimula las carreras en solitario, desatentas de quienes llevaron antes la antorcha, y premia el lucimiento que en sus mayores, en cambio, fue signo de perseverancia, rigor y trabajo silencioso, por tanto, del desinterés de quien no busca otro premio a sus desvelos que el cumplimiento del deber en servicio de los demás. Por otra parte, como indudable es que el incesante progreso científico condena a la obsolescencia aun el rendimiento objetivo de un genio descomunal, así también llegará el instante en que lo que nuestro autor entregó a su amada disciplina será superado — del mismo modo que un afán perficiente, muy distintivo suyo, le permitió enriquecer año tras año la producción personal一. Pese a ello, somos de la opinión de que hay en la obra de Politoff elementos perdurables, cuya cabal comprensión requiere considerar el modo particular de investigar el Derecho que él asumió, vástago de una orientación espiritual que sabía ligar las reglas y los sistemas jurídicos a múltiples condicionamientos materiales. De la identificación de los hilos invisibles que unen la forma al fondo del Derecho penal, las generaciones venideras pueden obtener, según pensamos, gran provecho. Al efecto, ayuda proporcionar también una semblanza del individuo. $Y$ es que la obra científica tiene autor, ha sido engendrada por un ser creador, y quien no estudie la causa nunca podrá comprender plenamente el efecto.

Existen también consideraciones personales que nos animaron a componer la presente reseña, con su designio mitad biográfico, mitad bibliográfico. Pero

\footnotetext{
${ }^{4}$ Las notas que se menciona en el texto corresponden a cartas al director publicadas en el diario El Mercurio, de Santiago de Chile, por los profesores señores Jean Pierre Matus Acuña, Carlos Künsemüller Loebenfelder, Hugo Rivera Villalobos y Enrique Cury Urzúa, ediciones de los días 10, 15,17 y 20 de enero de 2010, respectivamente.
} 
Guzmán - Estudio Necrológico: Sergio Politoff Lifschitz...

hemos de silenciar los motivos de cariño que yacen tras estas cuartillas, con la esperanza de que el destinatario y su legado tengan un día mejor cantor ${ }^{5}$.

\section{Familia y años de formación}

Nuestro biografiado fue el mayor de los tres hijos de la pareja formada por doña Emilia Lifschitz y don Leonidas Politoff. Los apellidos de los padres, que castellanizaron los nombres propios más adelante, denotan el origen ruso de su linaje. Muy jóvenes, tuvieron que emigrar desde Ucrania y Rusia Blanca, la actual Bielorrusia, respectivamente, donde la vida civil estaba trastornada por las agitaciones políticas que precedieron la Revolución de 1919, así como por pogromos y otros actos de hostilidad contra la población judía, organizados y permitidos para desviar la atención de los problemas que sacudían al gobierno zarista. Tras numerosas peripecias, que les hicieron asentarse provisoriamente en distintos países, arriban a París, destino natural de los refugiados rusos de la sazón. Allí se enamoran y contraen nupcias en julio de 1929.

Pasan a Chile. En Santiago, ciudad que adoptan como residencia, nace el 22 de abril de 1930 su primogénito, al que inscriben con el nombre Sergio Isidoro Politoff Lifschitz. El continente americano brindó a los jóvenes consortes el clima de serenidad indispensable para consolidar y hacer crecer la familia. Pronto llegan Paulina y Alberto, que con el tiempo destacarán en sus profesiones - como abogada la primera y profesor de Medicina el segundo-y por su amor a las artes y la poesía. En casa reinan el afecto, una tolerancia en la que no consiguió hacer mella la histórica incomprensión contra un pueblo oprimido, la sensibilidad artística y, en general, un ambiente culto. La madre, hija de un distinguido profesor, había estudiado Odontología en Europa, maneja varios idiomas, es amante de la literatura y sigue con interés las corrientes políticas. Por su parte, el padre culmina en 1940 los estudios de Derecho y ejerce como abogado penalista, defendiendo a la clientela que recibe en su propia casa, que albergaba el despacho, con una personalidad comprensiva, que es lo mismo que decir humana, y procurando mitigar la tragedia que implica para los allegados del preso el paso por

\footnotetext{
${ }^{5}$ En la reconstrucción de su trayectoria individual, académica y editorial nos hemos valido de la consulta de sus obras, de las que poseíamos y conocemos casi todas, pero también de nuestras correspondencia epistolar y conversaciones con él, así como del testimonio de amigos de más luenga data, especialmente los profesores señores Manuel de Rivacoba y Rivacoba (1925-2000), en cuya compañía departí con Politoff en algunas oportunidades y del que recuerdo con precisión hechos importantes que me relató de éste, Jaime Vivanco Sepúlveda y Enrique Cury Urzúa, quienes le fueron aún más próximos. Quiero agradecer muy especialmente a la señora Paulina Politoff Lifschitz los antecedentes familiares que me proporcionó de su hermano, incluso unas preciosas Memorias escritas por la madre de ambos. Vaya también mi gratitud al profesor señor Juan Carlos Cárcamo Olmos, antiguo Secretario del Instituto de Ciencias Penales de Santiago de Chile, por sus gestiones y mediación en mi búsqueda de las fuentes de la Necrología, y a los miembros del Seminario de Derecho penal de la Universidad de Valparaíso, especialmente el señor Enrique Aldunate Esquivel, por sus comentarios e indicaciones bibliográficas.
} 
una sala de justicia. Tales elementos, en que se funden inteligencia, ternura y cosmopolitismo, serían decisivos en la vocación, las cualidades intelectuales y el temple moral del hijo mayor.

Éste cursa la secundaria en el Liceo de Aplicación. Al título del benemérito instituto, uno de los más antiguos del país, hace honra con rigor y seriedad en los estudios, características que imprimirá en todas las tareas que la vida le puso por delante. Lee profusamente buena literatura, incluidos los clásicos, experiencia que estimula en él una extraordinaria facilidad para la redacción y, andando el tiempo, el desarrollo de un estilo preciso y hermoso de escribir, que le permitirá expresar en párrafos breves, claros y sugestivos cuestiones muy difíciles, a menudo abstrusas. Las lecturas de la doctrina marxista son emprendidas con la misma rectitud que los deberes escolares. El poso de las meditaciones filosóficas y políticas, que le harán profesar el comunismo, se amolda dócilmente a una filantropía ingénita, sensible al dolor del prójimo y a las contradicciones de la sociedad chilena — antaño y hogaño tremendamente desigual, discriminatoria y clasista- Participa en la Federación de Estudiantes, entregándose a la causa sin intereses pequeños, los que no podían hallar intersticio por el que filtrarse en un individuo que tuvo temprana conciencia de la libertad del hombre y los derechos nativos de su dignidad, generoso, modesto y, por ende, enemigo de toda figuración. Durante la fase del liceo conoce a Francisco Grisolía. Une a ambos la estirpe emigrante ${ }^{6}$ y una cálida amistad destinada a perdurar. Asimismo, la vocación jurídica, para la cual poseían sobradamente los requisitos de capacidad e interés, al igual que la determinación de consagrarse a ella en una corporación pública, laica y abierta.

Politoff mantiene su compromiso político durante la licenciatura, pero se concentra en los estudios jurídicos. Conviene mencionar que la brillantez de los resultados asume tonos especiales si se la contrasta con la feliz conjunción de talentos reunidos en la mocedad estudiantil de la Universidad de Chile promediando los años cincuenta. No pocos de sus coetáneos alcanzarían lugares de privilegio en la teoría y práctica de la Ciencia del Derecho, comenzando por los de inclinación penalista, sabiamente dirigidos por el profesor Álvaro Búnster Briceño, apenas una década mayor que sus alumnos. Con él se formarán, entre otros, Grisolía y Jaime Vivanco Sepúlveda, redactores de unas valiosas tesis de grado sobre el objeto jurídico del delito y el robo con homicidio, respectivamente,

\footnotetext{
${ }^{6}$ Grisolía había llegado muy joven a Chile a bordo del Winnipeg, el barco que fletó el poeta Pablo Neruda, en el papel de cónsul especial de emigración en Francia, para traer al país a refugiados de la República española. La nave atracó en el puerto de Valparaíso el 3 de septiembre de 1939 con dos mil doscientos pasajeros, entre hombres, mujeres y niños — como Grisolía—. El nombre de éste y los de sus padres, Francisco y Pilar, figuran en el registro reproducido por Jaime Ferrer Mir, Los españoles del Winnipeg. El barco de la esperanza, Ediciones Cal Sogas, Santiago de Chile, 1989, págs. 122 y 128.

7 Francisco Grisolía, El objeto jurídico del delito. (Prolegómenos para el estudio de la objetividad jurídica en los delitos de falsedad documental), Santiago de Chile, 1959, y Jaime Vivanco Sepúlveda, El delito de robo con homicidio. Ensayo de una interpretación a la luz de la doctrina del delito-tipo,
} 
Guzmán - Estudio Necrológico: Sergio Politoff Lifschitz...

y, por cierto, Sergio Politoff. Éste eligió como tema el delito de apropiación indebida, a cuya investigación se aplicó con ahínco por espacio de largos meses, cual si debiese preparar una tesis doctoral. El producto final, en 1956, corrobora la suposición. Se trata de un análisis completo y bien documentado de la historia, el objeto jurídico y la estructura típica de la infracción ${ }^{8}$. Por eso mereció la nota de sobresaliente, una encomiástica glosa en los Anales de la Facultad ${ }^{9}$ y los Premios José Clemente Fabres y Pedro Ortiz Muñoz, con que lo galardonaron en 1957 el Colegio de Abogados y el Instituto de Ciencias Penales como la mejor memoria de licenciatura ${ }^{10}$. Ese año ve la luz pública precedido de un prólogo de Búnster, en que el maestro elogia la "limpidez y armonía" con que el discípulo expresa sus múltiples ejercicios dialécticos, lo fluido de su razonar y "el claro equilibrio en que resultan dispuestos, en una superior síntesis creadora, el propio juicio y lo que resta de la crítica sin desmayo a que es sometido el pensamiento ajeno"11. En una palabra, el talento, moneda rara — por paradójico que pueda sonar- en la universidad, pero de la que Búnster disfrutaría en insólita abundancia con esos muchachos "que anunciaban una nueva época en los estudios jurídicos chilenos" 12 . La creación en palabra, y el ulterior quehacer del creador, no lo defraudarán. El libro es todavía de consulta ineludible y, en opinión de algunos críticos, la mayor monografía existente sobre el delito en nuestro idioma ${ }^{13}$.

Del propio 1957, cuando inicia el ejercicio forense, datan sus primeras colaboraciones a la entonces muy prestigiosa Revista de Ciencias penales del homónimo Instituto santiaguino, lo mismo que la adscripción a la cátedra del

Editorial Universitaria, Santiago de Chile, 1957 (reimpreso por Editorial Jurídica ConoSur, Santiago de Chile, 2000).

${ }^{8}$ En el aparato bibliográfico, principalmente español e hispanoamericano, no faltan obras italianas, francesas y alguna de Alemania, índices de la versación idiomática de que hará gala el autor en su futura producción, pero también, misteriosamente, del hado emigrante que le estaba reservado, según podemos afirmar ahora de quien cita el Código penal suizo, con preceptos "proporcionados por gentil atención del distinguido jurista de Berna, Dr. Dorian Lifschitz", y Los viajes de Gulliver, de Swift.

9 "Por la paciente, profunda y talentosa investigación que revela, por su impecable metodización, por la amplitud de su contenido, que agota la materia en todos sus aspectos, el trabajo del señor Politoff se encuentra a la altura de las mejores monografías que se han escrito sobre el delito de apropiación indebida..." Anales de la Facultad de Derecho de la Universidad de Chile, Tercera época, vol. III, enero a diciembre de 1956, número 5, Información sobre el Seminario de Derecho penal.

10 El Diploma del Instituto se le entregó en una ceremonia realizada en el edificio de calle Huérfanos harto después, el 21 de enero de 1971.

${ }^{11}$ El delito de apropiación indebida. Prólogo de Álvaro Búnster. Editorial Nascimento, Santiago de Chile, 1957, pág. 5. Huelga manifestar que, en su enojosa profusión de citas ajenas y su ayuno de ideas originales, la mayoría de las tesis doctorales sobre temas punitivos que se publica actualmente en ciertos países no serían dignas de esa apreciación, que conviene a lo que se espera de un verdadero trabajo de doctorado.

12 Ibídem.

${ }^{13}$ Fue reimpresa sin alteraciones en 1987 por la Editorial Jurídica Ediar-ConoSur. Su sucesora, la Editorial Jurídica ConoSur, alumbra en 1992, siempre en Santiago de Chile, una nueva edición, actualizada y prologada por Manuel de Rivacoba y Rivacoba (págs. V-IX). 
profesor Búnster, de momento como Ayudante, luego Investigador (1960) y Profesor auxiliar (1963). En el ínterin, había contraído matrimonio con Adriana Kohan Fernández, condiscípula en la Facultad. De su mano viaja en 1961 a Roma, en goce de una beca de estudios, para profundizar los conocimientos en la Escuela de Especialización en Derecho penal y Criminología de la Universidad La Sapienza. La vieja Scuola di Applicarione Giuridico-Criminale, que creó Ferri en 1911 y lideran después Arturo Rocco, Filippo Grispigni y Tullio Delogu, entre otros, no había perdido el sesgo criminológico del fundador, si bien los directores sucesivos supieron equilibrarlo con la impronta dogmático-jurídica. Tras dos años de dura labor, en que sobrelleva con alegría y optimismo los aprietos de mantener a cuatro personas con una simple pensión ${ }^{14}$, Politoff se diploma suma cum laude merced a la tesis Gli elementi soggettivi della fattispecie legale. El denso escrito aparece en castellano en 1965, tras ampliarlo con investigaciones realizadas en el Seminario de Búnster ${ }^{15}$. De nuevo estamos ante un libro magnífico, no sólo por la falta de exploración del asunto en el medio hispanoamericano — tarea que aquél satisfizo cabalmente-, sino por el magistral tratamiento que aquí reciben el debate instaurado en torno a tales elementos típicos, su distinción de otros componentes subjetivos del delito en los sistemas neoclásico y finalista, y su diferencia de los elementos subjetivos de la justificación. En el proverbial escepticismo de nuestro homenajeado ante los últimos, recelo que se remonta al pliego en cuestión, han de haber influido el estudio directo de la doctrina italiana, tan adversa a aquéllos como cuidadosa es al sopesar las teorías germánicas, y especialmente las reflexiones jurídico-políticas del secuaz chileno. Las páginas que comentamos son conscientes de que mientras los elementos subjetivos del tipo ciñen el ámbito de lo injusto punible, aquellos que se proclama como condicionantes de la exclusión del injusto producen el efecto opuesto, esto es, extienden el poder penal del Estado en una indagación pública de la intimidad de los justiciables. Basándose en Lukacs, sostiene Politoff que "no hay ninguna doctrina «inocente», y de ahí que nos resistamos a aceptar concepciones que tienden a subordinar en todo caso la antijuridicidad material a la ética, porque de esto al Derecho penal «del carácter» hay sólo un paso"16. Más adelante veremos que el autor ahondará en las bases de su aserto, para develar el trasfondo ideológico de las doctrinas del injusto personal y la culpabilidad por el carácter.

\footnotetext{
${ }^{14}$ Habían nacido ya los dos pequeños hijos de la familia, Leonidas y Lydia. Recuerdo una anécdota que el padre me refirió de la estancia en Roma, bien reveladora de su sentido del humor, aquí tocado por el espíritu italiano. Al salir un día de la Universidad vistiendo una gastada chaqueta cuyo bolsillo aparecía sucio con tiza de pizarrón, una comprensiva señora le señaló la mancha, a lo que él respondió, con socarrona resignación: “Fa' niente: sono un poveraccio!".

${ }^{15}$ Los elementos subjetivos del tipo legal. Prólogo de Álvaro Búnster. Editorial Jurídica de Chile, Santiago de Chile, 1965. Hay una segunda edición, con Presentación de Gonzalo Fernández y Revisión general de José Luis Guzmán Dalbora, B. de F., Montevideo-Buenos Aires, 2008.

16 Ídem, pág. 52 (de la $2^{\mathrm{a}}$ ed).
} 
Guzmán - Estudio Necrológico: Sergio Politoff Lifschitz...

\section{Ciencia y abogacía hasta 1973}

El volumen sobre los elementos subjetivos del tipo inauguró la Serie de Publicaciones del Seminario de Derecho penal y Medicina legal. El dato no carece de importancia para las ocupaciones de Politoff desde su regreso de Europa en 1963. Durante el decenio siguiente, de feraz siembra en los campos científico y profesional, el Seminario, juntamente al Instituto de Ciencias Penales y su órgano de difusión, son los ejes de su desempeño como docente e investigador. A poco de cesar en la dirección del Seminario (1963-1965), Búnster tiene la satisfacción de ver promovido al discípulo a la calidad de Profesor extraordinario de Derecho penal por la Universidad de Chile en Santiago, y de Derecho penal profundizado en la sede de Valparaíso $(1966)^{17}$. Los mismos estudiosos que animaban el debate penalista en la Facultad, nutrían el Instituto y la Revista: Juan Bustos, Enrique Cury, Alfredo Etcheberry, Francisco Grisolía, Armando Uribe, Jaime Vivanco, Sergio Yáñez, entre otros. El nuestro será al cabo de este período miembro del directorio del primero y, muy pronto, del consejo de redacción de la segunda, para cuyas secciones escribe una plétora de notas de jurisprudencia, recensiones de libros y publicaciones periódicas, así como relevantes artículos. El ambiente de cooperación imperante en ella queda inmortalizado en la advertencia editorial de que un asterisco puesto junto al nombre del autor, indicaba la colaboración de los colegas del Seminario. Esto, asociado a la generosidad de Politoff, explica que, de lo mucho que él escribió para sus páginas, no todo luzca bajo su nombre, algo que se repetirá en tareas de mayor aliento y en otras esferas, según diremos luego.

Los artículos no forman un número abultado, pero sí regalan calidad técnica. El estudio Omisión de socorro y homicidio por omisión ${ }^{18}$, escrito con Juan Bustos y Claudio Flisfisch, demuestra, con una aplicación inteligente del método sistemático de interpretación, la relevancia típica de las omisiones impropias en el Código chileno, discurre sobre los puntos de fricción entre éstas y la legalidad penal, y esboza límpidamente la diferencia entre ambos delitos a partir de la posición de garante del hechor. En la repulsa de la discriminación subjetiva, es decir, que el dolo o las motivaciones del agente permitiesen desplazar la omisión de un tipo a otro, se revela el nervio político del pliego. Los autores estiman que dicho criterio es contrario al liberalismo que informa al Código y a una sociedad que se quiere pluralista, motivo por el cual su legislación sólo puede penar actos

\footnotetext{
17 La sede porteña de la Universidad de Chile adquiere autonomía y se convierte en la actual Universidad de Valparaíso en 1981, por orden del régimen militar. Queriendo el mal, éste, sin embargo, produjo un bien, no sólo debido al desarrollo que alcanzarían los centros regionales después de desprenderse de las Universidades de Chile y Técnica del Estado, sino porque uno de ellos albergará a nuestro universitario a su retorno del exilio, en 1996.

18 Revista de Ciencias Penales, Tercera época, septiembre-diciembre de 1966, número 3 (tomo XXV), págs. 163-184.
} 
que la dañen, no erguirse en medio de perfeccionamiento individual ${ }^{19}$. Guarda concordancia con ello que aquí se rebata la difundida idea de que la omisión de socorro protegería o fomentaría la solidaridad humana, que no es bien jurídico alguno, sino una mera idealidad que tiñe al Derecho de ribetes moralizantes, y aquella que la vincula a una función asistencial que el Estado delegaría en el primero que llega junto al necesitado, por ser un "puro constructivismo teórico" que "incorpora al Derecho penal bienes jurídicos tan amplios e informes que impedirían determinar con precisión y claridad, como lo requiere también el principio de reserva, el ámbito de la antijuridicidad" ${ }^{\prime 20}$. El trabajo conjunto prosigue en Los delitos de peligro ${ }^{21}$, estudio rubricado sólo con Bustos, donde se argumenta la entidad real del peligro y su pertenencia al núcleo del tipo, con el consiguiente descarte de un dolo in re ipsa y los delitos llamados de peligro abstracto. La presunción incontrovertible de riesgos para el bien jurídico y el castigo de meras desobediencias, inherente a estas atormentadas figuras, socava la estructura del delito dentro de un Derecho penal liberal, arguye Politoff, con el ojo puesto en los de apología, propaganda o difusión de ciertas doctrinas o pensamientos, que rematan en la parálisis del libre comercio de las ideas y el castigo de la disidencia, si no se exige en la conducta la aptitud de generar un peligro para la estabilidad de las instituciones. Por consiguiente, "la verificación, caso por caso, de la relación de probabilidad del desvalor, en que el peligro consiste, es el límite tácito de los delitos de peligro, más allá del cual empieza la zona de libertad"22. Idéntica preocupación por preservar la autonomía del hombre en la formación de su conciencia y en la adopción de sus decisiones más importantes, se lee en un pequeño volumen independiente sobre la significación jurídico-penal de la esterilización consentida ${ }^{23}$.

El siguiente artículo es una pieza de Derecho penal comparado. De nuevo en disfrute de una beca, Politoff viaja en 1969 a estudiar en la Universidad Karl Marx de Leipzig la legislación y doctrina de la República Democrática Alemana. Con un nuevo diploma de especialización bajo el brazo, a su retorno emprende con Bustos el proyecto de traducir al castellano el entonces recentísimo Código penal del Estado socialista ${ }^{24}$, y asume el deber de informar personalmente a los

\footnotetext{
19 "Cuando el juicio penal de desvalor se afinca exclusivamente en el elemento subjetivo, como es el caso de la tesis expuesta, la consideración del daño social objetivo se substituye por una valoración del individuo mismo y, en el fondo, se recurre a criterios éticos ajenos al Derecho”. Ídem, pág. 175. 20 Ídem, págs. 183-184. Palabras que parecen escritas para el elefantiásico Derecho penal de nuestros días.

${ }^{21}$ Revista de Ciencias Penales, Tercera época, enero-abril de 1968, número 1 (tomo XXVII), págs. 3548.

22 "Esta verificación es también indispensable en los delitos llamados de peligro abstracto, sin que obste a ello el silencio de la ley al describir las conductas". Ídem, pág. 41.

${ }^{23}$ Juan Bustos, Elio de la Vega y Sergio Politoff, V asectomía y Derecho penal. Escuela de Salubridad de la Universidad de Chile, Santiago de Chile, 1969.

${ }^{24}$ Había entrado en vigor el $1^{\circ}$ de julio de 1968. Su vigencia acabó el 3 de octubre de 1990, tras el derrumbe de Alemania Oriental y la reunificación germana. Para los pormenores de la adopción del Código de la República Federal en los territorios orientales, véase Albin Eser, en Adolf Schönke y
} 
Guzmán - Estudio Necrológico: Sergio Politoff Lifschitz...

compañeros del Instituto las peculiaridades de dicho texto con su incipiente reconstrucción científica. La conferencia, cuya versión escrita data de principios del año siguiente ${ }^{25}$, se enfrentaba a un doble problema. Por una parte, la incertidumbre de entusiasmar con un Código del socialismo denominado real a un auditorio de tradiciones liberales —en lo que el orador se confió precisamente al clima de tolerancia todavía reinante en $\mathrm{Chile}^{26}$-, y, por otra, la improbable conciliación de los preceptos penales de un régimen totalitario con el respeto de la individualidad del hombre, tan cara a nuestro compatriota. Ambas dificultades hallan una liquidación magistral en la selección temática que éste desenvolvió. Con vasto apoyo en la doctrina del país oriental, Politoff trata de demostrar el arraigo culpabilista del Código de 1968, sólo que al socaire de una concepción socialmente modulada de la libertad del hombre, conforme a la cual "mientras mayor sea el margen social que el individuo reciba", mientras mayores sean las posibilidades que se le otorgó, "mayor será el grado de su libertad". Éste, a su vez, ha de determinar el grado concreto de su responsabilidad penal. En otras palabras, para el expositor este Código tomó inspiración en un entendimiento normativomaterial de la culpabilidad que no fulmina al justiciable con un reproche dictado por la superioridad moral, la arrogancia farisaica de quien lo formula, sino considera el influjo de la sociedad en la génesis del delito, incidencia que se traduce en "una responsabilidad correlativa a la del individuo"27. En seguida, Politoff aborda la recepción del principio de insignificancia y las formas de desjudicialización que el Código admite para delitos que muestren escasa antisocialidad, cuya sanción, consistente en unas medidas educativas, confía a comisiones empresariales y vecinales. Quizá el empeño de armonizar el documento con el liberalismo punitivo no podía tener en esto el éxito que el hablante se propuso; pero se puede convenir en su conclusión de que algo podía aprender nuestro medio jurídico de algunos aspectos de aquél, si es verdad que "la tragedia del Derecho penal es una tragedia que incumbe a la sociedad toda", y que "del delito son responsables delincuente y sociedad"28. Digamos de pasada que el disertante no abandonará este planteamiento en posteriores trabajos sobre el fundamento de la culpabilidad y la reducción del Derecho penal contemporáneo.

Horst Schröder, Strafgesetz̧buch. Kommentar. C.H. Beck'sche Verlagsbuchhandlung, München, $25^{\mathrm{a}}$ ed., 1997, págs. 5-6.

${ }^{25}$ El nuevo Código penal de la República Democrática Alemana, en Revista de Ciencias Penales, Tercera época, enero-abril de 1970, número 1 (tomo XXIX), págs. 3-14.

26 "Sé que me ayudará una saludable tradición de nuestro medio científico: su espíritu abierto, su lúcida curiosidad. Porque el fanatismo y los odios de sectas o escuelas nunca han llegado a este recinto a dividirnos en bandos irreconciliables”. Ídem, pág. 4.

27 Ídem, pág. 6. Sin usar el término, aquí se alude ostensiblemente a la coculpabilidad (en alemán, porque el concepto fue acuñado en ese idioma, Mitschuld). Pese a su raíz de prístino liberalismo, en Georg Jellinek y Moritz Liepmann, una parte de su historia discurrió, con efecto, en el Código y la doctrina germano-orientales, como apunta Zaffaroni, Derecho penal. Parte general. Con la colaboración de Alejandro Alagia y Alejandro Slokar. Ediar, Buenos Aires, $2^{\mathrm{a}}$ ed., 2002, cfr. pág. 656 (que ofrece adicionales referencias bibliográficas).

28 Ídem, pág. 14. 
Provisto ya de dominio de su materia, manejo del Derecho penal extranjero en fuentes directas - conocimiento alcanzado gracias a una capacidad asombrosa de expresarse a la perfección, oralmente y por escrito, en muchos idiomas de los pueblos cultos-, con una obra conocida en el concierto internacional, que le vale invitaciones para profesar su ciencia en universidades y otros centros doctos de aquende y allende el Atlántico, la curiosidad intelectual condujo a Politoff a concentrarse en los delitos en particular. Tal vez sea apresurado hablar de una concentración de sus intereses, porque éstos le impulsarían de una cuestión problemática a otra, sin importar su ubicación en el sistema ni, por otra parte, sucumbir a las seducciones de la versatilidad. Esta consideración ha de tenerse muy a la vista en llegando al volumen sobre la Parte especial del Derecho penal chileno ${ }^{29}$, al que hay que despejar de ciertos malentendidos. La obra se proyectó en seis tomos, al hilo de un sistema anunciado por el único que alcanzó estampa en letras de molde ${ }^{30}$. Que se haya podido culminar sólo éste, quedando los restantes en boceto, no se puede atribuir a inconstancia, defecto ajeno al temperamento del autor, sino lo impuso la emergencia de tener que abandonar trabajo, biblioteca, casa y país por orden de un régimen tiránico. En otro sentido, pese a firmarlo dos compañeros de la Universidad, con quienes ha de haber discutido cada uno de los temas, el libro fue escrito por una sola persona. Cualquiera que conozca el estilo, lo mismo que su manera de aquilatar las fuentes bibliográficas —examinadas en el contexto histórico, cultural e ideológico al que pertenecen-, advertirá que esta es obra de Sergio Politoff Lifschitz ${ }^{31}$. Por cierto, esta aclaración cede en importancia si se recuerda los lisonjeros juicios que en el Prólogo dedica a las tres figuras don Luis Jiménez de Asúa (1889-1970), a lo largo de párrafos que tornan superfluo comentar a nuestra vez un texto bien armado, completo dentro de su limitación, de redacción precisa y elegante — como el autor-, muy indicado para el aprendizaje de los delitos contra el individuo en sus condiciones físicas, asaz gravitante en la jurisprudencia y superior a otros de su género que habían aparecido en el ínterin ${ }^{32}$.

\footnotetext{
${ }^{29}$ Juan Bustos, Francisco Grisolía y Sergio Politoff, Derecho penal chileno. Parte especial. Tomo I (único publicado), Ediciones Encina, Santiago de Chile, 1971 (con varias reimpresiones por distintas editoriales; la última, en 2006).

30 Ídem, cfr. págs. 41-44.

31 Él mismo me lo confidenció en una conversación privada el año 1998, explicándome que no puso inconveniente en rubricarlo con sus colegas, porque eran las materias que ellos preparaban y explicaban juntos en la Universidad. Personas muy próximas a él, cuyos nombres omito en obsequio de la discreción, me ratificaron la exactitud de la confidencia.

32 Hay que apuntar, aunque sea en nota de pie de página, que uno de los raros deméritos del libro radica en cierta germanización en el entendimiento de los requisitos de algunos tipos, como la muerte del paciente en el auxilio al suicidio y el homicidio en riña. Cfr. páginas 336-337 y 346, que la consideran en ambos casos cual condición objetiva de punibilidad. A decir verdad, en el conjunto de la obra del autor se advierte una propensión a divisar estas últimas en varias infracciones, pese a ser consciente de la dificultad de conciliarlas con los principios de actividad y culpabilidad.
} 
Guzmán - Estudio Necrológico: Sergio Politoff Lifschitz...

Para el desempeño simultáneo de una actividad científica de esta envergadura con la abogacía, fontana de cotidianos sobresaltos que asedian la tranquilidad requerida por el investigador, hacen falta aptitudes y fuerzas que no están al alcance sino de cabezas privilegiadas. Pues bien, el lustro en que alumbra óptimas publicaciones es también de un intenso ejercicio forense del profesor Politoff. Compartir oficina con Gonzalo Bulnes Aldunate, un amigo civilista, facilitó la adecuada distribución de los negocios del bufete, reservando los penales, claro está, al ingenio del especialista. Ponemos ejercicio forense del profesor, porque éste, en efecto, lo fue también en aquél, algo que consta en relevantísimas causas en que le tocó intervenir y podemos presumir de otras muchas, no rodeadas del clamor público, pero que él ha de haber patrocinado con la misma sabiduría que documentan sus notas a fallos penales. Por cierto, el más resonante de aquellos procesos fue el seguido contra los responsables de la muerte del comandante en jefe del ejército, general René Schneider Chereau, asesinado en octubre de 1970 por fanáticos de derecha con el objeto de provocar una intervención armada que impidiese la asunción en la primera magistratura del país al candidato electo el mes anterior. Los alegatos de Politoff, quien representó a la familia del occiso, consiguieron la condena de los ejecutores directos y de los hombres que estaban detrás de la obscura trama, mediante un impecable empleo del concepto de autoría mediata, entonces ayuno de tratamiento científico en el medio nacional ${ }^{33}$.

Su reconocida capacidad profesional le valió la convocatoria al cargo de abogado del Ministerio del Interior durante la presidencia de Salvador Allende Gossens. Allí preparará causas, dictámenes y oficios de supino valor en un período muy delicado de la sociedad y las instituciones políticas chilenas. Como en otras ocasiones, algunos de los documentos no correrán con su firma, aunque hay buenos motivos para suponer que fue él quien redactó, por ejemplo, la respuesta del gobernante a la Corte Suprema, que lo había acusado de provocar, "no ya una crisis en el Estado de Derecho [...], sino un perentorio o inminente quiebre de la juridicidad del país" ${ }^{34}$.

El quiebre ocurre finalmente el 11 de septiembre de 1973, cuando se abate sobre Chile una tragedia en que se conjugaron "con mano maestra el encierro, el entierro y el destierro" 35 . Sólo la intervención del azar preservó a Politoff, señalado en los bandos entre las personas buscadas por los militares, de acabar preso, acaso

\footnotetext{
${ }^{33} \mathrm{El}$ alegato, junto al del representante del gobierno de la época, profesor Jorge Mera Figueroa, serían reproducidos en el volumen El caso Schneider, Editorial Quimantú, Santiago de Chile, 1972, págs. 69-119.

34 Oficio de 26 de mayo de 1973, que comunica un acuerdo del pleno del máximo tribunal. Baso la conjetura, entre otros elementos privados de respaldo, en lo que me refirió personalmente en 1996 mi maestro, Manuel de Rivacoba. La respuesta de Salvador Allende a la Corte Suprema puede leerse en el Apéndice del libro de Eduardo Novoa Monreal, Derecho, política y democracia. Un punto de vista de izquierda. Temis, Bogotá, 1983, págs. 203-214.

${ }^{35}$ Rivacoba y Rivacoba, Prólogo a su edición de El delito de apropiación indebida, citada supra, nota 13, pág. VI.
} 
de algo peor. Pero no lo libraría del exilio. Habían transcurrido cuarenta y tres años desde el arribo de sus padres a Santiago. Ahora tocaba a él, en el medio del camino de la vida, probar en carne propia el dolor de la emigración.

\section{El exilio}

La aciaga mañana de septiembre sorprende al jurista y a su mujer en Cuba. Aquí comienza un largo periplo que los hará radicarse primero en Leipzig, donde la familia reside el período más extenso, y luego en Ginebra, conllevando hasta el final, con dignidad, discreción y elegancia, la malaventura del extrañamiento. Perdido para la universidad chilena, que no tendrá noticia de sus pasos durante el régimen sedicioso, Politoff “jamás desistió de sus deberes ciudadanos ni dejó, por tanto, de pugnar por la recuperación de las libertades avasalladas" ${ }^{\$ 6}$, aplicándose a la tarea con las armas del oficio. De esta fase, que se prolonga hasta 1980, datan actividades e investigaciones en el ámbito de los derechos fundamentales ${ }^{37}$, así como un renovado interés por los problemas de política criminal.

Puede que haya contribuido a estimularlo el aparato de sospecha y vigilancia que celaba la vida de los exiliados en Alemania oriental, con el presumible desencanto de un hombre convencido del valor de la libertad, y, sobre todo, la llegada de éste a Holanda, ese viejísimo reducto de tolerancia. Resulta en extremo sintomático de la evolución político-jurídica de nuestro autor, el partido que él tomó en un momento en que se controvierte por doquier así la legitimidad del ius puniendi como su capacidad de contribuir a la resolución de problemas sociales. Politoff no polemiza con la pujante Criminología crítica, lastrada de un trasfondo marxista que termina por justificar el derecho de castigar ${ }^{38}$, y, en cambio, opta por confrontarse con el abolicionismo de Hulsman. Trae al español el ensayo sobre las peines perdues ${ }^{39}$, adjuntándole un cautivante epílogo que insinúa un espectro de consideraciones que él desplegará con más pormenores después. Allí

\footnotetext{
36 Ibídem.

${ }^{37}$ En las que no cejó durante la década sucesiva, como documentan los artículos Adecuación social y terror en América Latina: el papel de la Justicia, en Derecho penal y Criminología, vol. VII, número 22, enero-abril de 1984, págs. 71-81 (con versiones holandesa, Rechters in militaire dictaturen, en Nederlands Juristenblad, número 13, marzo de 1984, págs. 377 y ss., e italiana, Adeguatez̧a sociale e terrore nell'America Latina: il ruolo della Giustižia, en Dei delitti e delle pene, número 2, 1984), y Dogmática y vida de los derechos humanos en los regimenes autoritarios de América Latina, en Anales de la Cátedra Francisco Suárez, números 26-27, 1986-1987, págs. 34 y ss. Véase, antes, el artículo Justicia y fascismo, que data de 1978 y publicó Araucaria de Chile, número 3, págs. 3-8, principal revista de los chilenos en el exilio.

${ }^{38}$ Se entiende que no el Derecho penal de las sociedades capitalistas, sino uno cifrado en la tutela de esos «intereses socialmente relevantes» de la nomenclatura de Alessandro Baratta. Cfr. Criminologia critica e critica del diritto penale. Introduzione alla sociología giuridico-penale. Il Mulino, Bologna, 1982, pág. 97.

${ }^{39}$ Louk Hulsman y Jacqueline Bernat de Celis, Sistema penal y seguridad ciudadana: hacia una alternativa. Prólogo de Juan Bustos Ramírez y Postfacio de Sergio Politoff. Ariel, Barcelona, 1984.
} 
Guzmán - Estudio Necrológico: Sergio Politoff Lifschitz...

postula la urgencia de abandonar la pretensión, compartida lo mismo por la Dogmática occidental que la del socialismo real, de basar el reproche penal en el prestigio metafísico y la superioridad moral del Estado que castiga, en otras palabras, el hegelianismo tan caro a la ciencia penal tudesca. Considera que dicha pretensión es insostenible después del horror de Auschwitz, tanto más durante la risueña primavera de los ochenta, cuando "en todos los terrenos se cuestionan los deberes del individuo frente al Estado y se reivindican [...] la no violencia y la

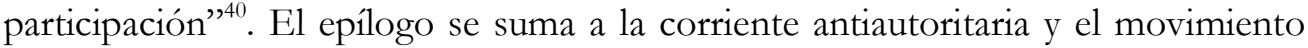
descriminalizador, pero no abraza todos los planteamientos del abolicionismo, por temor a que la pérdida de las garantías del Derecho penal liberal, en la búsqueda de un quid que lo reemplace, culmine en algo más nocivo que lo que se buscó suprimir $^{41}$, y por el imperativo de preservar los derechos básicos de las personas, especialmente las más vulnerables, ante el atropello del poder estatal y los grupos que obran a través de él. A su juicio, la perspectiva abolicionista implica reducir en lo factible el Derecho penal, pero no para dejar en su sitio el vacío; restará competencia al sistema, sí, mas sólo en la medida en que la alternativa que se proponga signifique un avance en el reconocimiento de la libertad y la dignidad del hombre.

Sin mengua de otros artículos sobre el particular ${ }^{42}$, Politoff se sumerge en el argumento a través de un lúcido examen de la legitimación política de la materia criminalista en el Estado de Derecho, oportunidad que representó, además, el reencuentro con los lectores hispanoamericanos ${ }^{43}$. Trata aquí de esa pareja antagónica de tradiciones formada por el Estado autoritario, en sus modalidades de derecha e izquierda, y el Estado liberal, con particular atención al paradigma holandés. El primero y los epígonos del binomio «amigo-enemigo», son sometidos a una crítica minuciosa además de reveladora, porque un profundo rastreo histórico deja de manifiesto los lazos ideológicos y la funcionalidad práctica de la teoría del injusto personal, con su indagación en el ánimo de los justiciables (el

\footnotetext{
40 Ídem, pág. 135.

${ }^{41}$ El realismo de «pedir lo imposible» le hace abjurar, pues, del vaticinio de Jiménez de Asúa, según el cual la Criminología pudiera llegar a tragarse al Derecho penal, y "las promesas de los clásicos del marxismo de que, en la sociedad sin clases, el Estado se irá adormeciendo y extinguiendo, y con él la represión". Ídem, pág. 132.

42 Por ejemplo, Living chances to the «impossible», en The criminal justice system as a social problem: an abolitianist perspective. Liber Amicorum Louk. Hulsman, editado por John Blad, Hans van Mastrigt y Niels Uidriks, Rótterdam, 1987, págs. 93 y ss.; Descriminalización y tutela jurídica, en Derecho penal y Criminología, vol. VIII, números 27-28, septiembre-diciembre de 1985 y enero-abril 1986 (con versiones holandesa, Decriminalisering en rechtsbescherming in wisselende contexten, en Recht en Kritiek, año 13, número 2, 1987, págs. 109 y ss., e italiana, Decriminalizzazione e tutela giuridica, en Dei delitti e delle pene, cit., número 21, 1986, págs. 215 y ss.), y Democracia y descriminalización, en Cuadernos ESIN, Ediciones INC, Rótterdam, número 24, 1983, págs. 17 y ss.

43 Sistema jurídico-penal y legitimación politica en el Estado democrático de Derecho, en Nuevo foro penal, de Bogotá, número 45, julio-septiembre de 1989, págs. 313 y ss. El artículo fue reproducido en Gaceta Jurídica, de Santiago de Chile, número 172, octubre de 1994, págs. 10-22, cómo pródromo del regreso del autor al país. Dos años antes tuvo versión en italiano.
} 
Gesinnungsstrafrecht o Derecho penal de la actitud interna), respecto del esquema de Carl Schmitt, de todo lo cual aún resuenan ecos en fórmulas estereotipadas de la Dogmática $^{44}$. Parejamente incisiva es la denuncia de la supervivencia del modelo aquel en algunos sectores de la izquierda contemporánea, que divisan en el delincuente un enemigo del pueblo. En contrapartida, las páginas ensalzan el liberalismo del Derecho penal neerlandés, depurado de supuestos autoritarios, plural, realista y con sentido práctico, que no se propone ser un "poder espiritual que da forma a la vida del pueblo" y, por ende, castiga el delito en cuanto lesión de bienes jurídicos de importancia social, no por la tendencia inmoral del agente. El estudio concluye que hay que conformarse con una legitimación mínima, pero éticamente responsable del Derecho penal, "en aquellos casos en que su retórica simbólica y su práctica instrumental puedan servir todavía para proteger a los débiles contra la violencia privada y favorezcan el aseguramiento de la vigencia y extensión de los derechos humanos" ${ }^{\prime 4}$.

Pero volvamos a Holanda. En 1980 la Universidad Erasmus, de Rótterdam, contrata al reputado jurisconsulto para enseñar en sus aulas Derecho penal comparado, ofreciéndole incluso, para comodidad de su docencia, que imparta las clases en inglés —idioma que conocía a la perfección, como el alemán, italiano y francés-. Pero él, quien poseía una elevada conciencia de su misión como educador y albergaba un sentimiento de gratitud hacia el país que lo acogió, declina la halagadora propuesta y aprende en pocos meses la lengua vernácula hasta dominarla. Va de suyo que semejante disposición, que le adentró asimismo en el ordenamiento jurídico, la historia y la cultura de los Países Bajos, tenía que granjearle también la cátedra de Derecho penal, desde la que investigará y explicará los siguientes quince años. El huésped retribuiría a sus anfitriones con una incesante producción volcada principalmente a la dogmática. Aparte de ensayos breves sobre el injusto y la culpabilidad en las situaciones de subyugación humana que ennegrecen la historia del siglo $\mathrm{XX}^{46}$, asunto que no abandonará tampoco al jubilarse, escribe en colaboración con Erik Koopmans un libro sobre la culpabilidad cuyo mérito lo incorporó a la bibliografía oficial para la formación de los graduandos holandeses ${ }^{47}$. La aptitud de trabajo colectivo ${ }^{48}$, el maestro innato

\footnotetext{
${ }^{44}$ El delito como lesión de deberes, la culpabilidad como falta de lealtad hacia el Derecho, etc. En este sentido, Politoff se adelantó a la actual pesquisa, acometida por diversos investigadores europeos e hispanoamericanos, de los vínculos nazis de grandes nombres de la ciencia penal alemana (e italiana). La investigación ha sacado ronchas, en ningún lugar más que en España, pues nadie gusta de admitir que sus maestros o abuelos científicos secundaron doctrinas totalitarias, ni de ver conmovidas las bases de su paradigma teórico. Es nuestro deseo no incomodar a colega alguno relevando este aspecto de la investigación que comentamos.

45 Ídem, pág. 22 (de la edición chilena).

${ }^{46}$ Sergio Politoff y Erik Koopmans, «Bevoegd onrecht» een rechtsbegrip?, en Nederslands Juristenblad, 1992, págs. 538-540, y Sergio Politoff, Eeen «geharnaste» rechtstraditie: vriend/vijand paradigma en Gesinnungsschnüffelei-syndrom, en ídem, 1989.

${ }^{47}$ Sergio Politoff y Erik Koopmans, Schuld. Gouda Quint, Arnhem, 1988 (2a ed., 1991).

48 Del que es prueba, por si alguna faltase hasta este punto, el capítulo Criminal Law, Chile, que compone con Koopmans para la Enciclopedia de sistemas penales del mundo editada por Kluwer
} 
Guzmán - Estudio Necrológico: Sergio Politoff Lifschitz...

que anidaba en él, la excelencia de la obra, el encanto que dimanaba de su persona, invaden a alumnos y colegas del deseo de reconocerle. De hecho, al dejar la cátedra, en 1995, los últimos lo honran obsequiándole un Liber Amicorum ${ }^{49}$ en que el título, «con el Derecho en el viaje», indica precisamente ethos y pathos de este profesor en su peregrinar.

"Extranjero, cuando llegues a tu tierra, acuérdate de mí" —el ruego de Nausícaa hubiera sido innecesario para nuestro emigrante-. Politoff no olvidará a Holanda. Con el océano de por medio, sabrá de la aparición de unos Comentarios al Código penal neerlandés que le tuvieron como encargado de varios artículos ${ }^{50}$. Por lo demás, volverá a Rótterdam. Allí pasa los últimos años y en tierras bajas descansará su envoltura corporal. Mas no precipitemos las cosas, porque está de por medio un nuevo, intenso período en Chile.

\section{Reencuentro con el tiempo perdido}

Sergio Politoff regresa en 1996 imbuido de la firme determinación de volcar en Chile la experiencia ganada en Europa, especialmente las cogniciones que acrecentó durante la estancia holandesa. Devolver a los compatriotas, con acelerado trajín, los años que le robó la rebelión de 1973, significaba un reencuentro personal con el tiempo perdido y, más allá de eso, patentiza su estatura moral y compromiso universitario. Después de todo, nadie se hubiera extrañado de haber preferido él descansar de las batallas que libró por su ciencia, la libertad y la vida hasta la edad de jubilarse.

Sin embargo, el país que descubre Politoff tras veintitrés años de ausencia no era más, en múltiples sentidos, aquél que dejó en la hora del exilio. La mudanza en el tono político, la transformación del sistema de valoraciones de la sociedad, entre otros componentes de la herencia de $1980^{51}$, nos ponen sobre la pista de por qué él permaneció entre nosotros sólo un cuadrienio. Es más, la herencia de desdicha, que se manifestó también en el orden administrativo, hubo de golpearle de entrada. Politoff no se reincorpora a su alma mater, en lo que nos sentimos invitados a imaginar que hacerlo habría implicado aceptar la validez jurídica del decreto que lo destituyó del cargo, así como someterse a una evaluación de

\footnotetext{
International, La Haya, Boston y Londres, 1995 (en la 2 a edición, 1999, colaboró la profesora María Cecilia Ramírez Guzmán).

${ }^{49}$ Met Recht op de vlucht. Opstellen over (straf) recht aangeboden aan Sergio I. Politoff ter gelegenheid van zijn afscheid van de Erasmus Universiteit Rotterdam. Sanders Instuituut, Arnhem, 1995.

50 Strafrecht, tesk \& commentaar, dirigido por Tineke Cleiren y Hans Nijboer. Kluwer, Deventer, 1997. Politoff apostilla los artículos 2 a 8 (ámbito de validez de la ley penal), 355 a 380 (delitos en la función pública) y 462 a 468a (contravenciones en la función pública).

51 Año en que el régimen militar sanciona su Constitución. El sistema político y judicial de hoy la considera dotada de valor jurídico y en perfecta vigencia.
} 
antecedentes superflua de cara al brillo mundialmente reconocido de los suyos ${ }^{52}$. ¡Ay de Chile, que basas tu ordenamiento jurídico en reglas espurias ${ }^{53}$ y obligas a tus hijos distinguidos a demostrar lo que cualquiera puede ver! Afortunadamente, Talca, una pequeña pero briosa ciudad del valle central chileno, abre sus puertas al célebre estudioso. De 1996 a 1999 él firmará sus obras como ex profesor extraordinario de la Universidad de Chile y profesor titular de la Universidad de Talca $^{54}$.

¡Y qué prodigio de publicaciones el de aquellos cuatro años! Cómodamente instalado en la ciudad, donde llegó a adquirir una casa, explica, investiga y escribe a raudales, en una atmósfera privilegiada por el sostén de las autoridades de la institución y la compañía de jóvenes estudiosos con los que volverá a ensayar la probada fórmula del trabajo conjunto. La fertilidad de su pluma se despliega en artículos, capítulos de libros colectivos, un curso, dos manuales y un comentario al Código penal, con páginas que comprenden asuntos de política criminal, filosofía jurídico-penal, historia contemporánea del derecho y dogmática de pura cepa, para la que trata actualísimos problemas de las partes general y especial. A los tres primeros grupos temáticos pertenecen un estudio en que continúa anteriores investigaciones sobre el abolicionismo y redondea su postura personal, que anticipó en algunos años el Derecho penal mínimo de Luigi Ferrajoli ${ }^{55}$; otro, donde aborda el vínculo entre conmensuración y fines de la pena, guiado del designio de conciliar las exigencias retributivas con los costes individuales y sociales de la punición $^{56}$; un agudo comentario a los fallos pronunciados por la justicia alemana

\footnotetext{
52 Según testimonio fidedigno, don Sergio, de cuyos labios no brotaban palabras de queja contra su suerte ni contra nadie en particular, tampoco gustaba de comentar este episodio. En cambio, es de conocimiento público el trance, análogo, que afectó a Eduardo Novoa Monreal, quien realizó infructuosamente gestiones administrativas tendentes a derogar el decreto que lo exoneró de la Universidad, trámite del que se supo a través de un duro intercambio de cartas de periódico con las autoridades de la institución. Véase Beatriz Guerra Guerrero, Eduardo Novoa Monreal: vida, obra e influencia dogmática en el Derecho penal actual. Memoria de grado (inédita) dirigida por Jean Pierre Matus Acuña, Universidad de Talca, 2005.

${ }^{53}$ No hay en esto una pizca de exageración, sino la evidencia simple de una realidad incontestable, amén de ventilada en procesos contra el Estado chileno en el plano internacional. Como explicó el testigo propuesto por éste a la Corte iberoamericana de derechos humanos en la causa sobre la desaparición de Luis Alfredo Almonacid (sentencia de 26 de noviembre de 2006), "si se consideran inválidas las normas dictadas por los gobiernos de facto en Chile, buena parte del ordenamiento jurídico caería, incluyendo muchas de las normas que otorgan legitimidad al actual sistema político". La elocuencia de estas expresiones, emitidas por don Jorge Correa Sutil, luego ministro del Tribunal constitucional, ahorra comentarios sobre semejante legitimidad.

${ }^{54} \mathrm{La}$ calidad de profesor titular, equivalente a la de catedrático en España, había substituido la designación de profesor ordinario, tomada de la terminología alemana e italiana, en la reforma de los reglamentos académicos de las Universidades derivadas de la central, que ocurre a finales de los años ochenta y principios de los noventa del siglo pasado.

55 Derecho penal con mesura: una respuesta reduccionista a la mala conciencia del jurista, en la revista Universum, de la Universidad de Talca, año 10, 1995, págs. 95-106.

56 Fines de la pena y racionalidad en su imposición, en la revista Ius et praxis, de la Universidad de Talca, año 4, número 2, 1998, págs. 9-16.
} 
Guzmán - Estudio Necrológico: Sergio Politoff Lifschitz...

en las criminales operaciones Euthanasia y Reinhard del terror nacionalsocialista ${ }^{57}$; un informe de política legislativa que aprueba la introducción al Derecho interno de un delito con que sancionar actos y expresiones discriminatorios contra individuos o grupos de personas por motivos raciales, religiosos, étnicos, etc. ${ }^{58}, \mathrm{y}$, en fin, una penetrante travesía histórico-sistemática que presenta la raíz autoritaria y las consecuencias prácticas de los elementos subjetivos de la justificación, oportunidad en que torna a la carga contra la doctrina del injusto personal ${ }^{59}$. En verdad, el último ensayo se hace eco de la advertencia nietzschiana de que necesitamos la historiografía, no para recrearnos como el malcriado haragán que se pasea por el jardín del saber, sino porque es un deber del científico cerciorarse en persona, esto es, aquilatando por sí mismo los méritos de un sistema antes de prohijarlo, de que camina por un jardín y no en una ciénaga ${ }^{60}$.

Pasando a la dogmática del Derecho penal de su país, Politoff encabezará un proyecto de investigación relativo a los delitos de estupefacientes. Ante una materia tan maltratada por la legislación — supuesto que merezcan el nombre de leyes unas reglas espasmódicas, errátiles, ayunas de técnica, ciegas a la realidad doliente de los desamparados, irracionales en sus supuestos y desproporcionadas hasta la crueldad en sus consecuencias-, sorprende que un penalista serio mida armas con el vástago perfecto del Derecho penal autoritario o, como se acostumbra a calificarle hoy, «del enemigo», máxime considerando la antipatía del autor por la doctrina política de que proviene el engendro. Sin embargo, él era de la opinión de que el riesgo de aparecer enfrascado en una scienza schifosa, con el consiguiente desmedro de su prestigio como estudioso, era menos grave que entregar este grupo de disposiciones a las contingencias intuitivas o los automatismos exegéticos de una praxis oscilante entre la severidad y la indulgencia. Y hay que decir en su favor que no se trazó el propósito de sistematizar la

${ }^{57}$ La justicia al servicio de la verdad histórica. Escolios acerca de la tesis doctoral de Dick de Mildt, «In the name of the people. Perpetreiters of genocide in the reflexion of ther post-war prosecution in West Germany. The 'euthanasia' and 'Aktion Reinhardt' Trial cases», La Haya 1996. En Ius et praxis, cit., año 3, número 2, 1997, págs. 283-291. De este contexto forma parte, además, El poder de la memoria. Reflexiones en torno al Diario de Victor Klemperer, ídem, año 6, número 1, 2000, págs. 513-522.

58 Informe sobre los delitos de discriminación en el Derecho penal comparado. (A la luz del Proyecto de ley sobre discriminación racial y étnica [Boletín $N^{0}$ 2142-17]), en Ius et praxis, cit., año 5, número 2, 1999, págs. 193-313. El dominio de la legislación comparada le hace caer, empero, en el extendido error de pensar que la dignidad humana constituye un bien jurídico. En otro lugar tenemos escrito que la equivocación proviene de confundir un atributo de la persona (la dignidad, que es constitutiva de su esencia) con aquellos elementos que posibilitan su conservación en el disfrute de dicha prerrogativa (los bienes jurídicos). Cfr. nuestro Estudio preliminar, en colaboración con Agustín Squella Narducci, al libro Estado de Derecho y dignidad bumana, de Werner Maihofer, B. de F., Montevideo Buenos Aires, 2008, págs. (IX-XXXII) XIX-XX.

${ }^{59}$ El papel del factor subjetivo en las causas de justificación, en Luiz Luisi, Manuel de Rivacoba y Rivacoba, José Luis Guzmán Dalbora y Sergio Politoff Lifschitz, Política criminal y reforma penal. Editorial Jurídica ConoSur, Santiago de Chile, 1996, págs. 67-107.

${ }^{60}$ La cita de Nietzsche, en Walter Benjamin, La dialéctica en suspenso. Fragmentos sobre la historia. Traducción, introducción, notas e índices de Pablo Oyarzún Robles. Lom Ediciones, Santiago de Chile, $2^{a}$ ed., 2009, pág. 47. 
cuestión, porque todo sistema supone una organización racional del pensamiento, fundada, a su vez, en la racionalidad intrínseca del objeto de ese contenido intelectual. En cambio, los estudios, muy meritorios, que elaboró sobre puntos específicos, ponen en ellos orden y concierto, contribuyendo efectivamente a un manejo racional dentro la insensatez irremediable que aqueja al conjunto ${ }^{61}$.

Por fortuna, el Derecho penal común chileno todavía permite diseños sistemáticos. Politoff asume el desafío en las postrimerías de 1996, para dejarnos al año siguiente el primer volumen de una Parte general ${ }^{62}$. Originado en los materiales de clase que preparó para los alumnos, el libro brinda una inteligente introducción a la disciplina, seguida de una teoría del delito en que la reconstrucción del ordenamiento nacional es contrastada a cada paso con la legislación y doctrina extranjeras, principalmente la holandesa, todo ello dentro de un sistema de factura neoclásica, abierto, moderno y atento a las consecuencias político-criminales de las soluciones teóricas, antes que a "la armonía y elegancia de los paradigmas escogidos por los escritores o a apriorismos supuestamente ontológicos" ${ }^{\prime 3}$. La obra fue ideada en cuatro tomos, mas hay que tener presente que todo plan individual de trabajo está sometido a la cruz del tiempo, a la provisionalidad de las circunstancias que gravitan en el que lo concibió, motivo por el cual ninguna acción considerable ha obtenido jamás todos los resultados que de ella se esperaba. Consciente de esto, Politoff reorienta su foco y completa el sistema dándole una salida editorial distinta. Así llegará la monografía sobre el iter criminis, capítulo faltante en la Parte general, que repasa al efecto las opiniones de juristas extranjeros, "no en una especie de continum de ideas sueltas, que se pueden escoger con prescindencia del contexto cultural y de la tradición de que forman parte", defiende los principios liberales que inspiraron al Código chileno en la regulación de la tentativa y destaca la prioridad, tanto política como científica, de los criterios objetivos en el deslinde entre actos preparatorios y de ejecución ${ }^{64}$. Por último, en colaboración con sus discípulos en la Universidad, redondea el sistema, compendiándolo para usos didácticos, en dos manuales dedicados

\footnotetext{
${ }^{61}$ Cfr. Sergio Politoff y Jean Pierre Matus, Objeto jurídico y objeto material en los delitos de tráfico ilícito de estupefacientes, en el volumen coordinado por ambos, Tratamiento penal del tráfico ilícito de estupefacientes. Estudios de Dogmática y jurisprudencia. Editorial Jurídica ConoSur, Santiago de Chile, 1998, págs. 3-52; Sergio Politoff, El agente encubierto y el informante «infiltrado» en el marco de la Ley $N^{0} 19.366$ sobre tráfico ilicito de estupefacientes y sustancias psicotrópicas, ídem, págs. 53-87; La conspiración para cometer delitos previstos en la Ley sobre tráfico de estupefacientes, ídem, págs. 89-109, y El lavado de dinero, en Lavado de dinero y tráfico ilícito de estupefacientes, libro también coordinado por Politoff y Matus, Editorial Jurídica ConoSur, Santiago de Chile, 1999, págs. 3-86.

${ }^{62}$ Derecho penal. Tomo I (único publicado). Editorial Jurídica ConoSur, Santiago de Chile, 1997.

${ }^{63}$ Ídem, pág. X del Prefacio del autor.

${ }^{64}$ Los actos preparatorios del delito, tentativa y frustración. Estudio de Dogmática penal y de Derecho penal comparado. Editorial Jurídica de Chile, Santiago de Chile, 1999.
} 
Guzmán - Estudio Necrológico: Sergio Politoff Lifschitz...

respectivamente al ajuste de la Parte general y dar un panorama de los delitos más importantes de la Parte especial ${ }^{65}$.

No creemos ser ésta la ocasión de justipreciar los manuales, por demás premiados con el favor del público, ni el Comentario al Código penal que codirigió, emulando el holandés, con el fin de entregar al jurista práctico, en párrafos claros y concisos, las informaciones que éste necesita en la aplicación de sus disposiciones ${ }^{66}$. Son libros recientes, conocidos por los jóvenes, a quienes la estrechez histórica del medio nacional nos sugirió ilustrar con mayor detenimiento acerca de textos más antiguos del autor. Digamos únicamente que se llevan a cabo estando él de regreso en Europa, tras emprender la última y definitiva emigración.

\section{De vuelta en Europa}

Hacia finales de 1999 supimos de su voluntad de pasar a retiro en Talca y volver a Europa como jubilado. Una llamada telefónica nos refirió los motivos manifiestos de la decisión. Por helados que quedamos ante la perspectiva de perder Chile, por segunda vez, a una figura tan productiva en la ciencia como cordialísima en el trato personal, nos embargó en el acto la viva impresión de que sus palabras ocultaban motivaciones latentes. Politoff adujo la lejanía de sus nietos, que crecían con padres europeos o europeizados en países distintos al otro lado del Atlántico; las limitaciones de la ciudad de asiento en Chile, que oprimían a un espíritu cosmopolita como el suyo; en fin, su incapacidad de comprender por qué el gobierno del país se había empeñado en defender al hombre que segó la democracia y destruyó a familias completas de la comunidad chilena, trayéndolo desde su regia prisión domiciliaria londinense a otra no menos suntuosa en el borde andino de Santiago. Sin embargo, tenemos para nosotros que en esa sociedad, muy cambiada durante la forzada ausencia, como antes dijimos, él ya no podía depositar la esperanza que alentó desde su juventud — que algún día el interés del hombre pueda coincidir con el de su prójimo, y el de todos los hombres, con el interés de la humanidad-. Tal representación, de la República asesinada $^{67}$, tenía que herir el alma del viejo maestro, a quien el desasosiego trashumante, para colmo, dejó como sedimento la idea de no pertenecer a paraje alguno, de estar él y su mujer en Chile solos o rodeados de pocos parientes y amigos. En suma, el drama del exilio.

\footnotetext{
65 Sergio Politoff, Jean Pierre Matus y María Cecilia Ramírez, Lecciones de Derecho penal chileno. Parte general. Editorial Jurídica de Chile, Santiago de Chile, $2^{a}$ ed., actualizada, 2006, y Lecciones de Derecho penal chileno. Parte especial. Editorial Jurídica de Chile, Santiago de Chile, $2^{\mathrm{a}}$ ed., 2005.

66 Texto y comentario del Código penal chileno. Tomo I (único publicado). Obra dirigida por Sergio Politoff Lifschitz y Luis Ortiz Quiroga, y coordinada por Jean Pierre Matus Acuña. Editorial Jurídica de Chile, Santiago de Chile, 2002.

${ }^{67}$ Es el nombre de un hermoso verso de Pablo de Rokha (1894-1968), poeta que intuyó los sucesos de 1973.
} 
El signo emigrante sellará también los últimos diez años de don Sergio. Él y doña Adriana pasan un período en Suiza y Francia, siempre en pos de la cercanía de hijos y nietos, para afincarse definitivamente en Rótterdam. Allí, pero también en Alicante, donde hallaron refugio de las inclemencias del invierno nórdico, el marido seguirá ocupado de la disciplina que tanto amó. Apuntamos ya que ultima su sistema penal en Europa, a lo que son de añadir dos contribuciones en memoria de Marino Barbero Santos (1929-2001) y Manuel de Rivacoba y Rivacoba (19252000) —otro peregrino de exilios_. En la tumba del primero depositará una completísima revisión histórica y comparativa del concepto de autoría mediata, que culmina en un razonamiento, muy propio de su teoría del delito caracterizada por una normativización que marcha al compás de los datos de la realidad y, por tanto, rehuye del autismo constructivista-, proclive a hacer responder penalmente a las personas jurídicas ${ }^{68}$. Para el homenaje a Rivacoba codirige el libro y entrega un sensacional estudio de las vicisitudes de la obediencia jerárquica en el siglo XX. Entiende que la prueba de la eximente en la experiencia de los crímenes de guerra y contra la humanidad, obliga a someter a una severa restricción el carácter vinculante de la orden superior de cometer actos ilícitos, límite al que no se substraen las órdenes destinadas a precaver ataques terroristas, con el conflicto de deberes correlativo para el llamado en principio a acatarlas ${ }^{69}$. Todavía en 2007 rinde una significativa aportación al conocimiento del progreso contemporáneo de la teoría del delito, al llevar a nuestra lengua, en impecable y elegantísima versión, el Tratado de M. E. Mayer ${ }^{70}$, obra que encarna la esencia liberal y democrática del neokantismo sudoccidental en las cuestiones penales. Por eso, y porque este molde neoclásico de la doctrina de la infracción criminal se avenía a pedir de boca con las inclinaciones de Politoff, éste acogió entusiasmado el proyecto de traducirlo, concluyéndolo en la superioridad garantizada por su inmensa capacidad. Nos consta que el producto le satisfizo sobremanera, no tanto por "el bon plaisir de se voir imprime", como me escribió en una carta, "sino por el convencimiento de haber hecho una contribución importante a la difusión de nobles ideas en el plano del Derecho penal, que sitúa al autor de una obra tan eminente, como corresponde, en el marco de los formidables anhelos del optimismo liberal y humanista, aplastados luego por el Estado criminal del nacionalsocialismo".

68 «Cometer» y «hacer cometer»: desarrollo y significación actual de la noción de autoría mediata. El «autor detrás del autor». De la autoría funcional a la responsabilidad penal de las personas jurídicas. En Homenaje al Dr. Marino Barbero Santos. «In memoriam». 2 vols. Ediciones de las Universidades de Castilla-La Mancha y Salamanca, Cuenca, 2001, t. I, págs. 1231-1284.

${ }^{69}$ Obediencia y delito en contextos cambiantes, en Jorge de Figueiredo Dias, Sergio Politoff Lifschitz, Alfonso Serrano Gómez y Eugenio Raúl Zaffaroni (directores), El penalista liberal. Controversias nacionales e internacionales en Derecho penal, procesal penal y Criminología. Homenaje a Manuel de Rivacoba. Hammurabi, Buenos Aires, 2004, págs. 529-562.

${ }^{70}$ Max Ernst Mayer, Derecho penal. Parte general. Traducción directa del alemán por el profesor Sergio Politoff Lifschitz, con Revisión general y Prólogo por el profesor José Luis Guzmán Dalbora. Editorial B. de F., Montevideo-Buenos Aires, 2007. 
Guzmán - Estudio Necrológico: Sergio Politoff Lifschitz...

Mas no hay capacidad intelectual que resista al deterioro fisiológico que irrogan los años, porque el pensamiento es esclavo de la vida, y la vida se deja engañar por el tiempo - aunque todos quisiéramos clamar, con Hotspur: jel tiempo debe detenerse $!^{11}$ - Poco antes de recibir del correo el volumen mayeriano, don Sergio es repentinamente aquejado de cáncer al colon. Una exitosa intervención quirúrgica y los celosos cuidados de doña Adriana consiguen restablecerlo en salud, con un muy feliz pronóstico. El tiempo, empero, diría otra cosa. Promediando 2009, en pleno período de remisión, se le declara en España una nueva forma de cáncer, esta vez pulmonar, que detiene su corazón unos meses después, en Rótterdam, a los setenta y nueve años de edad. Acaba así, en lejana morada, la existencia del profesor emigrante.

\section{E1 legado}

Al vadear el Estigia, Sergio Politoff Lifschitz dejó, con su vida y su obra, un legado a las nuevas hornadas de criminalistas. Pero hay que precisar los contornos del caudal deferido por modo de aprovecharlo plenamente.

Antes de comenzar el repaso de sus andanzas adelantamos la conclusión de que con la muerte de don Sergio llega a su eclipse una generación de penalistas chilenos. Queremos reafirmar esta apreciación, aunque también discutir la sombría hipótesis, que leímos en los días del ocaso, de que tendrán que pasar muchos años antes de que la ciencia penal de este país pueda mostrar nuevamente maestros de la talla de Politoff, "con su inteligencia poderosa, su ingenio sutil y agilísimo, su dominio de la disciplina que profesó, sus conocimientos insondables y su sólida formación clásica, unido todo ello a una sensibilidad exquisita, que hicieron de él, mucho más que un mero penalista de nuestro tiempo, un auténtico humanista"72.

Es cierto que los sucesos de septiembre de 1973 comportaron la pérdida o, a lo menos, el cercenamiento de la generación de juristas que debía continuar el trabajo de la que integró nuestro personaje. Pero no es menos exacto que existe hoy otro grupo de estudiosos, activo y vital, que ha retomado resueltamente el testigo de sus mayores. La inédita copiosidad editorial de los últimos años ${ }^{73}$, la dedicación académica de los jóvenes profesores, el ascendente de su pensamiento en el foro, la proyección internacional de su obra, el intercambio de ideas con colegas extranjeros, la pululante presencia de éstos en nuestros centros de estudio,

\footnotetext{
71 Shakespeare, La primera parte del Rey Enrique IV, acto V.

${ }^{72}$ Rivacoba y Rivacoba, Prólogo a su edición de El delito de apropiación indebida, citada supra, nota 13, pág. VI. No he hallado mejor descripción de la persona de don Sergio que la trazada por su amigo español, de la que sólo cambié los tiempos verbales para ajustarla al presente.

73 Documentada en Matus Acuña y Carnevali Rodríguez, Análisis descriptivo y cuantitativo de los articulos de Derecho penal y Criminología de autores chilenos en Revistas publicadas en Chile (1885-2006), en Política criminal, Revista electrónica semestral de políticas públicas en materias penales, de Santiago de Chile, número 3, 2007, D2, 1-138, disponible en internet, http://www.politicacriminal.cl/n 03/d 2 3.pdf [visitado el 2 de abril de 2010] .
} 
acreditan que el cultivo de la especialidad ha vuelto por sus fueros y está en condiciones de alcanzar, incluso superar el nivel técnico en que la dejaron los hombres de la vieja guardia. Es a ese grupo, precisamente, al que habla el mensaje de Sergio Politoff.

Su discurso no pretende aherrojar a nadie a un sistema determinado. Este autor desconfiaba de las ambiciones sistemáticas, que pueden transformarse en una enfermedad del carácter, detener la evolución del Derecho en un estadio determinado y, lo que es más grave aún, aniquilar la individualidad de los fenómenos de la vida. Por lo demás, la conducta humana está regida por normas, que no por la simetría estética de los sistemas. Se ha de aspirar, pues, a un sistema deliberadamente abierto, a un proyecto inconcluso y provisional que posibilite nuevos desenvolvimientos científicos.

Es aquí donde interviene el segundo timbre, del mismo tono pero más bajo que el anterior, del llamado de Politoff. Éste solía repetir que una ciencia sin conciencia no es sino ruina del alma. La metodología del criminalista no puede contentarse con axiomas ni prescindir de los condicionamientos políticos ${ }^{74}$ que yacen bajo las normas y las interpretaciones construidas sobre ellas. Tampoco ha de inclinarse ante el argumento de autoridad o plegarse al vaivén de las modas. Esto vale especialmente para los que tenemos que trabajar lejos de los principales centros de estudio del mundo, aunque no deja de poseer interés también en los últimos, porque es el único medio con que evitar la momificación de la ciencia o que ésta, en aras de una pretendida modernización, se entregue a aberraciones como las que exhiben capítulos completos del saber del siglo XX. En ello resulta imprescindible la formación humanista del jurisconsulto, para el cual los conocimientos especializados han de ser apenas un apéndice del entramado espiritual tejido con el estudio y la meditación de las mejores obras de literatura, poesía, arte, filosofía, historia y ciencias naturales. Aquí reside una parte de la grandeza de Sergio Politoff. Si él pudo codearse con lo más granado de la ciencia penal germánica y, al mismo tiempo, seguir con tanta independencia de criterio sus evoluciones, fue porque conocía a fondo la cultura de esos países merced a la lectura directa, por ejemplo, de Heinrich Heine.

Pero resta un timbre más grave, que es también el más importante, en la voz del maestro. La hechura del profesor universitario requiere coherencia entre la conducta y las convicciones, por supuesto, pero demanda también, imperativamente, firmeza moral en los trances de apremio, que son el fuego en que se forja el carácter. La tibieza en las actitudes, la conciencia indolente, el zigzagueo ante la multiplicidad de los desafíos o tentaciones de la vida civil, son incompatibles con el recto cumplimiento del deber como hombres de estudio y como ciudadanos. Circunstancias excepcionales enfrentaron a Politoff a pruebas máximas, de las que él pudo salir airoso porque sabía exactamente cuál era su deber y cuándo, dónde y cómo cumplirlo, lo que logró para triunfo de su

\footnotetext{
${ }^{74} \mathrm{Y}$ hoy, sobre todo, económicos, siquiera éstos responden siempre a intereses políticos.
} 
Guzmán - Estudio Necrológico: Sergio Politoff Lifschitz...

conciencia y admiración de los demás. ¡Pluguiera el cielo que sepamos hacer otro tanto en el perfeccionamiento de la universidad, la renovación de la democracia reconquistada y la búsqueda de un porvenir mejor para nuestros compatriotas! 
REJ - Revista de Estudios de la Justicia - No 12 - Año 2010

\section{BIBLIOGRAFÍA}

* BARATTA, Alessandro: Criminologia critica e critica del diritto penale. Introduzione alla sociología giuridico-penale. Il Mulino, Bologna, 1982.

* BENJAMIN, Walter: La dialéctica en suspenso. Fragmentos sobre la historia. Traducción, introducción, notas e índices de Pablo Oyarzún Robles. Lom Ediciones, Santiago de Chile, $2^{a}$ ed., 2009.

* Bustos, Juan/DE la VEGA, Elio/POLITOFF, Sergio: Vasectomía y Derecho penal. Escuela de Salubridad de la Universidad de Chile, Santiago, 1969.

* BUStos, Juan/GRISOlíA, Francisco/POlitofF, Sergio: Derecho penal chileno. Parte especial. Tomo I (único publicado), Ediciones Encina, Santiago, 1971.

* ESER, Albin (en Adolf Schönke y Horst Schröder): Strafgesetz̧buch. Kommentar. C.H. Beck'sche Verlagsbuchhandlung, München, 25ª ed., 1997.

* Ferrer mir, Jaime: Los españoles del Winnipeg. El barco de la esperanza, Ediciones Cal Sogas, Santiago, 1989

* GRISOLÍA, Francisco: El objeto jurídico del delito. (Prolegómenos para el estudio de la objetividad jurídica en los delitos de falsedad documental), Santiago, 1959.

* GUERRA GUERRERO, Beatriz: Eduardo Novoa Monreal: vida, obra e influencia dogmática en el Derecho penal actual. Memoria de grado (inédita) dirigida por Jean Pierre Matus Acuña, Universidad de Talca, 2005.

* HUlSMAN, Louk/BERNAT DE CELIS, Jacqueline: Sistema penal y seguridad ciudadana: hacia una alternativa. Prólogo de Juan Bustos Ramírez y Postfacio de Sergio Politoff. Ariel, Barcelona, 1984.

* MATUS ACUÑA. Jean Piere/CARNEVALI RODRÍGUEZ, Raúl: “Análisis descriptivo y cuantitativo de los artículos de Derecho penal y Criminología de autores chilenos en Revistas publicadas en Chile (1885-2006)", en Politica criminal, Revista electrónica semestral de políticas públicas en materias penales, de Santiago de Chile, número 3, 2007, D2, 1 138, disponible en internet, http://www.politicacriminal.cl/n $03 / \mathrm{d} 23$.pdf [visitado el 2 de abril de 2010] .

* MAYER, Max Ernst: Derecho penal. Parte general. Traducción directa del alemán por el profesor Sergio Politoff Lifschitz, con Revisión general y Prólogo por el profesor José Luis Guzmán Dalbora. Editorial B. de F., Montevideo-Buenos Aires, 2007.

* NOVOA MONREAL, Eduardo: Nacionalización, Derecho y propiedad. (Textos escogidos); Editorial Arcis, Santiago, 2006.

Derecho, política y democracia. Un punto de vista de irquierda. Temis, Bogotá, 1983.

* POlitOFF, Sergio: El delito de apropiación indebida. Prólogo de Álvaro Bunster. Editorial Nascimento, Santiago, 1957. 1965.

Los elementos subjetivos del tipo legal. Editorial Jurídica de Chile, Santiago de Chile,

_ Derecho penal. Tomo I (único publicado). Editorial Jurídica ConoSur, Santiago, 1997.

Los actos preparatorios del delito, tentativa y frustración. Estudio de Dogmática penal y de Derecho penal comparado. Editorial Jurídica de Chile, Santiago de Chile, 1999.

Texto y comentario del Código penal chileno. Tomo I (único publicado). Obra dirigida por Sergio Politoff Lifschitz y Luis Ortiz Quiroga, y coordinada por Jean Pierre Matus Acuña. Editorial Jurídica de Chile, Santiago de Chile, 2002.

"Living chances to the «impossible»", en The criminal justice system as a social problem: an abolitianist perspective. Liber Amicorum Louk Hulsman, editado por John Blad, Hans van Mastrigt y Niels Uidriks, Rótterdam, 1987 
Guzmán - Estudio Necrológico: Sergio Politoff Lifschitz...

"Descriminalización y tutela jurídica", en Derecho penal y Criminología, vol. VIII, números 27-28, septiembre-diciembre de 1985 y enero-abril 1986 (con versiones holandesa, Decriminalisering en rechtshescherming in wisselende contexten, en Recht en Kritiek, año 13, número 2, 1987. e italiana, Decriminalizzazione e tutela giuridica, en Dei delitti e delle pene, cit., número 21, 1986)

"Democracia y descriminalización", en Cuadernos ESIN, Ediciones INC, Rótterdam, número 24, 1983.

"Sistema jurídico-penal y legitimación política en el Estado democrático de Derecho”, en Nuevo foro penal, de Bogotá, número 45, julio-septiembre de 1989.

"Derecho penal con mesura: una respuesta reduccionista a la mala conciencia del jurista", en Universum, Universidad de Talca, año 10, 1995.

"Fines de la pena y racionalidad en su imposición", Ius et praxis, Universidad de Talca, año 4, número 2, 1998.

"La justicia al servicio de la verdad histórica. Escolios acerca de la tesis doctoral de Dick de Mildt, «In the name of the people. Perpetreiters of genocide in the reflexion of ther post-war prosecution in West Germany. The 'euthanasia' and 'Aktion Reinhardt' Trial cases»”, La Haya 1996. Ius et praxis, cit., año 3, número 2, 1997.

"El poder de la memoria. Reflexiones en torno al Diario de Victor Klemperer", Ius et praxis, año 6, número 1, Santiago, 2000.

"Informe sobre los delitos de discriminación en el Derecho penal comparado. (A la luz del Proyecto de ley sobre discriminación racial y étnica [Boletín No 2142-17])", en Ius et praxis, cit., año 5, número 2, 1999.

"El papel del factor subjetivo en las causas de justificación", en Luiz Luisi, Manuel de Rivacoba y Rivacoba, José Luis Guzmán Dalbora y Sergio Politoff Lifschitz, Política criminal y reforma penal. Editorial Jurídica ConoSur, Santiago de Chile, 1996.

“«Cometer» y «hacer cometen»: desarrollo y significación actual de la noción de autoría mediata. El «autor detrás del autor». De la autoría funcional a la responsabilidad penal de las personas jurídicas”. En Homenaje al Dr. Marino Barbero Santos. «In memoriam». 2 vols. Ediciones de las Universidades de Castilla-La Mancha y Salamanca, Cuenca.

"Obediencia y delito en contextos cambiantes", en El penalista liberal. Controversias nacionales e internacionales en Derecho penal, procesal penal y Criminología. Homenaje a Manuel de Rivacoba. Jorge de Figueiredo Dias, Sergio Politoff Lifschitz, Alfonso Serrano Gómez y Eugenio Raúl Zaffaroni (directores). Hammurabi, Buenos Aires, 2004.

* POLITOFF, Sergio/KOOPMANS, Erik: “«Bevoegd onrecht» een rechtsbegrip?”, en Nederslands Juristenblad, 1992.

Schuld. Gouda Quint, Arnhem, 1988 (2a ed., 1991).

* POlITOFF, Sergio/MATUS, Jean Pierre: El lavado de dinero, en Lavado de dinero y tráfico ilicito de estupefacientes, (coord.) Editorial Jurídica ConoSur, Santiago, 1999.

"Objeto jurídico y objeto material en los delitos de tráfico ilícito de estupefacientes”, en Tratamiento penal del tráfico ilícito de estupefacientes. Estudios de Dogmática y jurisprudencia. Editorial Jurídica ConoSur, Santiago, 1998.

"El agente encubierto y el informante «infiltrado» en el marco de la Ley No 19.366 sobre tráfico ilícito de estupefacientes y sustancias psicotrópicas", en Tratamiento penal del tráfico ilícito de estupefacientes. Estudios de Dogmática y jurisprudencia. Editorial Jurídica ConoSur, Santiago, 1998.

"La conspiración para cometer delitos previstos en la Ley sobre tráfico de estupefacientes", en Tratamiento penal del tráfico ilícito de estupefacientes. Estudios de Dogmática y jurisprudencia. Editorial Jurídica ConoSur, Santiago, 1998.

* POlITOFF, Sergio/MATUS, Jean Pierre; RAMÍREZ, María Cecilia: Lecciones de Derecho penal chileno. Parte general. Editorial Jurídica de Chile, Santiago de Chile, $2^{a}$ ed., actualizada, 2006. 
REJ - Revista de Estudios de la Justicia - No 12 - Año 2010

Lecciones de Derecho penal chileno. Parte especial. Editorial Jurídica de Chile, Santiago de Chile, $2^{\mathrm{a}}$ ed., 2005.

* URQUizO OLAECHEA, José (coord.): Modernas tendencias de Dogmática penal y Politica criminal, Idemsa, Lima, 2007.

* VILlegas DÍAZ, Myrrna (coord.): Contribuciones críticas al sistema penal de la post modernidad, Universidad Central en memoria de Eduardo Novoa Monreal, Santiago, 2008.

* VIVANCO SEPÚLVEDA, Jaime: El delito de robo con homicidio. Ensayo de una interpretación a la luz de la doctrina del delito-tipo, Editorial Universitaria, Santiago, 1957 (reimpreso por Editorial Jurídica ConoSur, Santiago de Chile, 2000).

* VV.AA: Anales de la Facultad de Derecho de la Universidad de Chile, Tercera época, vol. III, enero a diciembre de 1956, número 5, Información sobre el Seminario de Derecho penal. 1972.

"El caso Schneider", Documentos especiales. Editorial Quimantú, Santiago de Chile,

ZAFfaroni, Eugenio: Derecho penal. Parte general. Con la colaboración de Alejandro Alagia y Alejandro Slokar. Ediar, Buenos Aires, $2^{\mathrm{a}}$ ed., 2002. 